\title{
Imaging techniques for acute ischemic stroke: nice gadgets or essential tools for effective treatment?
}

\author{
Vincent Thijs
}

Received: 17 November 2009 /Accepted: 17 November 2009/Published online: 17 December 2009

(C) Springer-Verlag 2009

In this issue of Neuroradiology, two papers present a state of the art on computed tomography (CT) and magnetic resonance (MR) imaging of acute ischemic stroke [1,2]. These papers provide an excellent overview for the general neurologist and radiologist on established and newer imaging modalities available with MRI and CT that can be used in stroke imaging. The authors eloquently describe established early findings on $\mathrm{CT}$ or diffusion-weighted imaging, as well as newer techniques like susceptibility weighted MRI or perfusion imaging with CT.

These papers also address several important issues that are the object of current stroke imaging research. A burning question is which imaging modality is best suited for use in acute stroke, advanced CT, or MRI. Clearly, CT and MRI have their own advantages and disadvantages as described in Table 1. Still, with the increased sophistication of CT and MRI, we have to keep in mind that plain CT was used as the sole imaging modality in the only universally accepted treatment modality that we have available right now, intravenous tissue plasminogen activator [3, 4]. Even in the most recent successful trial of thrombolysis, CT was used as the imaging modality of choice [5]. At the same time, I think we have exhausted the way we can treat stroke using plain CT in many of the other treatment needs in acute stroke, as painfully illustrated by the abciximab in Emergency Treatment of Stroke Trial [6]. In this trial, reliance on $\mathrm{CT}$ to treat the patients who woke up with symptoms, led to disaster. Even relying on the concept of a "clinical CT mismatch", in which salvageable brain tissue

\section{Thijs $(\bowtie)$}

Department of Neurology, University Hospitals Leuven,

Herestraat 49,

B3000 Leuven, Belgium

e-mail: Vincent.Thijs@uz.kuleuven.ac.be is thought to be present based on a discrepancy between the severity of the clinical deficit and the relative absence of early imaging findings on $\mathrm{CT}$, did not lead to improved outcomes [7].

Probably, a direct comparison of advanced CT versus advanced MRI as the sole purpose of a randomized controlled clinical trial will never be performed. I would propose that this is also not the heart of the matter in stroke imaging. The most important question now is whether advanced imaging, be it CT- or MRI-based, will make a difference in how we treat acute ischemic stroke. Indeed, we still have to answer an important question: does our better diagnostic ability lead to better clinical outcomes?

Let us first examine what the current treatment needs are in acute ischemic stroke. At present, there is no established treatment option for the $20-30 \%$ of patients who wake up with stroke, yet we often suspect that these patients could benefit from acute recanalization be it by medication or by thrombectomy [8]. Even though intravenous thrombolysis is a successful treatment with a high average benefit compared to other treatments, there are a large number of patients who fail to respond or who suffer from reocclusion in the first hours after successful treatment [9]. Newer and safer thrombolytic agents are needed [10]. There is no established treatment option for patients who fall outside the accepted time window for thrombolysis and we have only limited ways of predicting treatment response for individual patients. There is weak evidence for supporting invasive stroke treatment, but this occurs at the cost of a high risk of intracerebral hemorrhage [11]. Even though recanalization with thrombectomy is a strong predictor of good outcome it does not always lead to improvement in all patients. Finally, there is a need for a neuroprotective strategy that can be used hand-in-hand with the current 'plumbing' approach. Clearly, the current treatment needs require a more sophisticated 
Table 1 Comparison of CT and MRI based techniques.

\begin{tabular}{lcc}
\hline & CT & MRI \\
\hline Sensitivity & - & + \\
Exclusion of acute intracerebral hemorrhage & + & + \\
Exclusion of old intracerebral hemorrhage & - & + \\
Exposure to radiation & + & - \\
Availability & + & - \\
Speed & + & - \\
Imaging of vessels & + & + \\
Imaging of vessel wall hematoma & - & + \\
Imaging of "penumbra" & + & + \\
Coverage of perfusion & - & + \\
Reliability of absolute perfusion values & + & $+/$ \\
Claustrophobia inducing & - & + \\
\hline
\end{tabular}

approach than the information offered by "time since stroke onset" and results of plain CT can answer. Each of these preliminary studies has shown that advanced neuroimaging can be powerful adjuncts in treatment decisions. For wakeup stroke, simple fluid-attenuated inversion recovery combined with diffusion-weighted imaging may indicate whether stroke falls within the current 3- or 4.5-h time window or not [12]. For the poor responders to intravenous thrombolysis, both MR and CT are able to provide information on the persistence or reappearance of vessel occlusion and the presence of salvageable tissue that is potentially aided by intra-arterial thrombolysis. MR and CT are potentially able to extend the time window by generating individualized imaging patterns that help stratify risk benefit $[13,14]$. This allows for more accurate prediction of intracerebral hemorrhage and poor or excellent treatment response to revascularization $[15,16]$. Novel neuroprotective agents can be tested in homogeneous patient groups with prespecified imaging characteristics, rather than the mix of patients typically tested in CT based trials, an approach which led to a graveyard of once promising neuroprotective agents.

If we want to convince health authorities that these tools are more than nice imaging gadgets, clinical trials that test these concepts and show actual clinical benefit for patients will be eventually required. The first steps in this direction were taken with studies like Diffusion-Weighted Imaging Evaluation for Understanding Stroke Evolution or Echoplanar Imaging Thrombolysis Evaluation Trial [13, 14]. However, they need to be replicated, expanded, and refined. These studies will require intimate cooperation between neurologists, neuroradiologists, and neurointerventionists. Too often in the past, these disciplines have lived side by side and did not listen to each other's needs. These studies will require standardization of definitions, image processing, and analysis that are accurate, but also feasible in the context of multicenter trials. They will probably require relatively large numbers of patients and will be quite costly given the advanced technology required. On the other hand, the numbers of strokes are so vast, and treatment needs so dramatic that the societal "return on investment" can be huge if we can prove that this approach is successful.

Conflict of interest statement $\mathrm{V}$ Thijs has received lecture honoraria and travel grants from Boehringer Ingelheim.

\section{References}

1. Lovblad K. Computed tomography in acute ischemic stroke (published same issue)

2. Kloska S. Acute stroke magnetic resonance imaging: current status and future perspective (published same issue)

3. Tissue plasminogen activator for acute ischemic stroke (1995) The national institute of neurological disorders and stroke rt-PA stroke study group. N Engl J Med 333(24):1581-1587

4. Lansberg MG, Bluhmki E, Thijs VN (2009) Efficacy and safety of tissue plasminogen activator 3 to 4.5 hours after acute ischemic stroke: a metaanalysis. Stroke 40(7):2438-2441

5. Hacke W, Kaste M, Bluhmki E, Brozman M, Davalos A, Guidetti D, Larrue V, Lees KR, Medeghri Z, Machnig T, Schneider D, von Kummer R, Wahlgren N, Toni D (2008) Thrombolysis with alteplase 3 to 4.5 hours after acute ischemic stroke. N Engl J Med 359 (13): $1317-1329$

6. Adams HP Jr, Effron MB, Torner J, Davalos A, Frayne J, Teal P, Leclerc J, Oemar B, Padgett L, Barnathan ES, Hacke W (2008) Emergency administration of abciximab for treatment of patients with acute ischemic stroke: results of an international phase III trial: abciximab in Emergency Treatment of Stroke Trial (AbESTT-II). Stroke 39(1):87-99

7. Kent DM, Hill MD, Ruthazer R, Coutts SB, Demchuk AM, Dzialowski I, Wunderlich O, von Kummer R (2005) "Clinical-CT mismatch" and the response to systemic thrombolytic therapy in acute ischemic stroke. Stroke 36(8):1695-1699

8. Fink JN, Kumar S, Horkan C, Linfante I, Selim MH, Caplan LR, Schlaug G (2002) The stroke patient who woke up: clinical and radiological features, including diffusion and perfusion MRI. Stroke 33(4):988-993

9. Saqqur M, Molina CA, Salam A, Siddiqui M, Ribo M, Uchino K, Calleja S, Garami Z, Khan K, Akhtar N, O'Rourke F, Shuaib A, Demchuk AM, Alexandrov AV (2007) Clinical deterioration after intravenous recombinant tissue plasminogen activator treatment: a multicenter transcranial Doppler study. Stroke 38(1):69-74

10. Thijs VN, Peeters A, Vosko M, Aichner F, Schellinger PD, Schneider D, Neumann-Haefelin T, Rother J, Davalos A, Wahlgren N, Verhamme P (2009) Randomized, placebo-controlled, doseranging clinical trial of intravenous microplasmin in patients with acute ischemic stroke. Stroke 40(12):3789-3795

11. Smith WS, Sung G, Saver J, Budzik R, Duckwiler G, Liebeskind DS, Lutsep HL, Rymer MM, Higashida RT, Starkman S, Gobin YP, Frei D, Grobelny T, Hellinger F, Huddle D, Kidwell C, Koroshetz W, Marks M, Nesbit G, Silverman IE (2008) Mechanical thrombectomy for acute ischemic stroke: final results of the multi MERCI trial. Stroke 39(4):1205-1212

12. Thomalla G, Rossbach P, Rosenkranz M, Siemonsen S, Krutzelmann A, Fiehler J, Gerloff C (2009) Negative fluid-attenuated inversion recovery imaging identifies acute ischemic stroke at 3 hours or less. Ann Neurol 65(6):724-732 
13. Albers GW, Thijs VN, Wechsler L, Kemp S, Schlaug G, Skalabrin E, Bammer R, Kakuda W, Lansberg MG, Shuaib A, Coplin W, Hamilton S, Moseley M, Marks MP (2006) Magnetic resonance imaging profiles predict clinical response to early reperfusion: the diffusion and perfusion imaging evaluation for understanding stroke evolution (DEFUSE) study. Ann Neurol 60(5):508-517

14. Davis SM, Donnan GA, Parsons MW, Levi C, Butcher KS, Peeters A, Barber PA, Bladin C, De Silva DA, Byrnes G, Chalk JB, Fink JN, Kimber TE, Schultz D, Hand PJ, Frayne J, Hankey G, Muir K, Gerraty R, Tress BM, Desmond PM (2008) Effects of alteplase beyond $3 \mathrm{~h}$ after stroke in the echoplanar imaging thrombolytic evaluation trial (EPITHET): a placebo-controlled randomised trial. Lancet Neurol 7(4):299-309

15. Lansberg MG, Thijs VN, Bammer R, Kemp S, Wijman CA, Marks MP, Albers GW (2007) Risk factors of symptomatic intracerebral hemorrhage after tPA therapy for acute stroke. Stroke 38(8):22752278

16. Singer OC, Humpich MC, Fiehler J, Albers GW, Lansberg MG, Kastrup A, Rovira A, Liebeskind DS, Gass A, Rosso C, Derex L, Kim JS, Neumann-Haefelin T (2008) Risk for symptomatic intracerebral hemorrhage after thrombolysis assessed by diffusionweighted magnetic resonance imaging. Ann Neurol 63(1):52-60 